\title{
Indian-American Identity Negotiation: Placing the Self in Domestic and Public Spaces
}

\author{
Marwa Fawzy
}

\section{Introduction}

Numerous attempts have been made at explicating the concept of 'identity' and studying the processes of identity construction, deconstruction, and reconstruction. These attempts are particularly significant in delineating the impact of displacement on transnational figures. When Vijay Mishra said: "All diasporas are unhappy, but every diaspora is unhappy in its own way" $(2007,1)$, he was referring to those people whose exploration of their identities in diaspora has placed them in an ambivalent position with regard to the meaning of their hyphenated identities and their need for a community. The same sad connotations were expressed by Edward Said in his "Reflections on Exile," where he described the experience of displacement or exile as one of sadness that cannot be defeated; even representations of the relatively successful "episodes in an exile's life [...] are no more than efforts meant to overcome the crippling sorrow of estrangement" $(2013,173)$. Though there are clear distinctions between diaspora, exile, and immigration, they all share the basic experience of dislocation and being cut from one's roots for a significant period of time.

In order to attain a nearly comprehensive understanding of such migrant/diasporic identities, a survey of 'identity' perceptions is in order. For Stuart Hall, identity is "a process of understanding - 'What we have become' rather than determining "what we really are" $(1990,225)$. In other words, the understanding of the self involves analyzing the factors that have left their marks on one's identity, especially the temporal factor. This view undervalues the importance of place as a determining factor of one's identity, a perception that is shared by Paul Gilroy who argues that identity "should not only be viewed in relation to one's birthplace or - roots; identity is a work in progress gradually

\footnotetext{
* Assistant Lecturer in English, The British University in Egypt (BUE). This paper is derived from the author's unpublished M.A. thesis entitled "Indian Diaspora and Identity Transformation in Selected Indian American Novels by Kiran Desai, Bharati Mukherjee, and Jhumpa Lahiri" (Cairo University 2017).

Cairo Studies in English - 2020(2): https://cse.journals.ekb.eg/
} 
determined by one's-routes" $(1993,19)$. Clearly, Gilroy allocates paramount importance to one's journey or course of action as indicative of the dynamic nature of identity, which can hardly be explained in relation to one's origins.

Furthermore, for other scholars, identity is a performance rather than a rigid state of sameness. For instance, in The Presentation of Self in Everyday Life, Erving Goffman compares people's expression of their identity in front of others to a performance where the audience "are asked to believe that the character they see $[\ldots]$ possesses the attributes he appears to possess, that the task he performs will have the consequences that are implicitly claimed for it" $(1956,10)$. In other words, identity is what one says and does, and by changing one's speech and behaviors, identities are likely to transform. This dynamic view entails that in order for the performance to happen, the audience should be willing to accept its reality.

Thus, this concept of identity as performance is comparable to Hall's 'enunciation' of the self where he asserts that "what we say is always 'in context,' positioned" (222). The speaker or writer uses the first-person pronoun 'I' to place himself/herself in a certain contextual background without which the identity can hardly be represented. The view that one's place and identity are interlinked is also upheld by Cynthia J. Miller, who stresses that one's sense of self, narrative, and history are all directly related to the recognition of a spatial and temporal context $(2008,284)$. Certainly, a strong or weak sense of self has its implications on one's relationships and choices. Hence, placing the self in a certain spatial context can substantially reveal the protagonists' sense of self.

\section{Internarrative Identity}

A model that ventures to establish a relationship between one's identity and place is significantly represented through Ajit K. Maan's 'Internarrative Identity.' Such a model is applied in this article to assess the paradigms of identity transformation. Following Paul Ricoeur, Maan's model could explain the forms of identity transformation as represented in the selected texts. The Ricoeurian approach to identity allows for a wide understanding of its ambiguity and duality, for Ricoeur conceptualizes two different senses of identity which he refers to as 'idem' (Latin for 'sameness') and 'ipse' (Latin for 'self') (Maan 2010, 73). These two concepts need to be distinguished from one another because identity is not sameness. Identity, for Ricoeur, is not merely a set of characteristics that stay the same over time (idem), it is, more importantly, the intentional self-identity (ipse) which one develops through exhibiting consistency against constantly changing circumstances (Maan 2010, xv). 
Ricoeur proposes, thus, a third use of identity which results from shuttling between idem and ipse, namely 'Narrative Identity.' He establishes his 'Narrative Identity' theory on three foundations: firstly, one's knowledge of oneself is merely an interpretation; secondly, this interpretation becomes more lucid through narrative mediation; thirdly, this mediation depends on history as well as on fiction which makes the subject's life story a "fictive history" or a "historical fiction" (73).

Maan applauds this perception of identity as it lends importance to intention as well as culture in identity formation. Nevertheless, she contradicts the traditional aspect of the theory which purports that narration of the subject's experiences has to follow the traditional Aristotelian aesthetics of unity or else these experiences will not be meaningful in their entirety. In other words, the narrative theory does not account for alternative narratives of the self, voices, and ways of being (Maan 2010, 45). That is to say, the construction of identity does not have to parallel the development of a linear plot nor should it be complete. Maan believes that the experiences of discontinuities can be the subject matter of the story and that cross-cultural experiences may be hard to synthesize (16). Maan's approach reflects a broader understanding of the subject's agency as evidenced through the way s/he chooses to narrate the story rather than the temporal development of events.

Alternatively, Maan's internarrative identity makes sense of the discontinuities in a story through spatial rather than temporal ties. Instead of understanding the "narrative" function as a technique that synthesizes experience, Maan conceives it as a means of "manipulating" and "re-associating experience" (Maan 2010, 45). Accordingly, the postcolonial narrator agency can be further enriched by redefining the self and defying traditional cultural norms instead of conforming to classical aesthetics. Maan adds that the internarrative identity can possibly engage in subversive identity performance and reversal of concepts (46). As a result, identity according to this model is established and reestablished through an extended agency that is demonstrated through the texts under study.

An essential concept that impacts identity transformation is that of personal agency, especially according to the 'performative' view explained above. Agency, as Sunil Bhatia argues, needs to be represented or "asserted" through an act, such as "justification, denial, deflection, resistance, or acceptance" (Bhatia 2007, 3-4). However, Bhatia does not use 'agency' to indicate a free will. It is rather a reflection of how the bigger political and cultural forces 'enable' and 'constrain' the agent (4). Hence, agency is fundamental in identity 
construction, and in the case of immigrants, it is relatively curtailed by the foreign setting and its requirements for cultural integration. A similar perception of agency is expressed by Stephen Slemon who defines it as "a question of who or what acts oppositionally, when ideology or discourse or psychic processes of some kind construct human subjects" (Slemon 1995, 50). In other words, agency is primarily asserted through resistance to the dominant culture.

Considering that personal agency is contingent upon one's cultural and national identity, it is crucial to investigate the relationship between one's agency, identity construction, and assimilation to the hosting culture. For Ashcroft, Griffiths, and Tiffin, the concept of agency refers to:

the ability to act or perform an action. In contemporary theory, it hinges on the question of whether individuals can freely and autonomously initiate action, or whether the things they do are in some sense determined by the ways in which their identity has been constructed. Agency is particularly important in post-colonial theory because it refers to the ability of post-colonial subjects to initiate action in engaging or resisting imperial power. $(1998,9)$

Thus, agency is an integral aspect of identity as it spells the difference between a dominant entity and a subjugated one. Having the agency of name-giving is tantamount to having power over the 'named' person. Furthermore, agency is a defining characteristic of those who can attain identity transformation and cultural assimilation.

Based on the above explanation of agency and identity, diasporic identities can be expressed through different acts of agency. Oonk discerns three possibilities to complete the self-identifying enunciation: the "assimilative" which identifies with the dominant group, the "acculturative" which identifies with a hybrid/hyphenated identity, and the "dissociative" which dissociates one from the hosting country and identifies with the ethnic minority (Oonk 2007, 204). These possibilities represent assimilation as a choice, a view that is not fully supported by this paper. Assimilation to the hosting culture is far more complex to be simply chosen or to describe a natural tendency to identify oneself with a certain group. Rather, assimilation is realized through numerous factors among which are agency and self/other-perception.

It is crucial to note that diasporic people are not a homogenous group with similar traits; their migrations, certainly, differ in terms of their reasons, challenges, and coping mechanisms. Accordingly, their diasporic experiences 
take different trajectories depending on their abilities or potentials to assimilate into the receiving culture and achieve financial and social success. The journey between dislocation and settlement in a new locale almost always has to happen through a 'middle passage,' which is no longer physically demanding in such an advanced globalized era. The major challenge for the migrants in crossing that 'middle passage' is to engage in a process of identity negotiation that helps them come to terms with the rupture of being dislocated.

\section{Diasporic Identity Negotiation}

Bharati Mukherjee's Jasmine (1989) and Jhumpa Lahiri's The Namesake (2004) are two literary representations of Indian diasporic figures and their related dynamics of cultural assimilation. Both texts illustrate transnational identity negotiation, and they seem to celebrate the transnational experience though not without concerns. Throughout the narratives, the protagonists psychologically traverse spatial and temporal spaces to bridge the gap that separates them from both the homeland and the host land. While they often yearn to return home, the host land in its own way becomes also 'home,' and while they have left a family behind, they may now have another family in their new setting.

Upon being dislocated, the immigrant's sense of place is heightened in a manner that may change his/her self-perception as well as his/her relations with others. This holds true especially in the case of immigrant women whose lives are disrupted by leaving their familiar domestic spaces and endeavoring to acquaint themselves with a foreign culture to which they should adjust in order to facilitate their living conditions. As Amritjit Singh and Peter Schmidt believe, immigration enhances identity-consciousness, so when women are the object of the Other's gaze, they become conscious of their "marked identity" in the host land $(2000,34)$. Such consciousness marks the onset of an identity conflict that some fail to resolve while others succeed for fear of becoming 'outsiders' to the mainstream culture in the host land or to alleviate their feelings of nostalgia to the homeland. Because of being away from the extended family, with whom they share a collective identity, the female protagonists in the two texts develop their own self-identity which turns their dislocation experience into an empowering one.

Although the two narratives adopt conflicting positions on assimilation and cultural identity, they share several commonalities. Firstly, they challenge the stereotypical depictions of Indian men and women. Secondly, both texts depict the process of placing the self within domestic and public spaces and the 
implications it has on the potential of one's cultural assimilation as well as identity transformation. With regard to cultural assimilation, Mukherjee tends to give her protagonists several opportunities for rebirth and integration. Her depiction of the title character, Jasmine, confirms that immigration for women is an invigorating experience that motivates them to create their own identityor identities - by giving them the agency they may have been denied at home. As for Lahiri's text, the first generation's response to immigration is both gendered and stereotypical. In other words, men are connected with the realm of 'doing,' while women are left to dwell in the realm of 'feeling:' "The husbands are teachers, researchers, doctors, engineers. The wives, homesick and bewildered" (Lahiri 2004, 38). Regarding the difference between Ashima and Ashoke's decision to immigrate, Ashima is following the path set forth by her traditional upbringing wherein she needs to relocate with her husband and help him pursue his dreams. On the other hand, as Ashoke challenges his parents' vision of his future (Ranasinha 2016, 197), it is evident that "his academic job in a university outside Boston is everything he ever dreamed of" (Lahiri 2004, 49), especially after he survived the train accident which granted him an opportunity for rebirth.

In fact, assimilation in both novels is a result of placing oneself within the American culture through overcoming the conflictual multiple narratives to which the diasporic subject belongs. According to Maan's Internarrative Identity theory, the subject can have more than one narrative and several selves that are not clearly distinct from one another $(2010,51)$. This entails that the subject identifies with more than one narrative and forms what Maan calls a "contingent identity" while crossing from one narrative to the next. For instance, in Mukherjee's novel:

Jyoti of Hasnapur was not Jasmine, Duff's day mummy and Taylor and Wylie's au pair in Manhattan; that Jasmine isn't this Jane Ripplemeyer having lunch with Mary Webb at the University Club today. And which of us is the undetected murderer of a half-faced monster, which of us has held a dying husband, which of us was raped and raped and raped in boats and cars and motel rooms? (Mukherjee 1989, 127)

Accordingly, Jasmine's identity fits Maan's model of the 'internarrative identity' which is always in a state of flux as long as the protagonist continues to narrate her story in her own voice and keeps living as a nomad. She leaves her homeland 
and embarks on a mission of honoring her husband and discovering herself, a journey that transforms her identity and self-perception. She has not settled for a long time in one place in America. She runs away from the motel in which she was raped, stays at Lillian Gordon's house and then moves to Taylor's house, then to Professor Vadhera's house, and then to Bud Ripplemeyer's house from which she runs away with Taylor in the final scene without a definite destination.

Her nomadic mobility is her means of irrevocably breaking the shackles of the past which keeps haunting her progress. By refusing to marry Bud Riplemeyer, Jasmine/Jane is defying the fortune-teller's prophecy of widowhood and exile prophecy which haunted her since she was still a child. She metaphorically kills the dutiful Indian woman inside her by escaping and anticipating what the future holds for her. She leaves Bud and runs away with Taylor, her previous employer who helped her become Americanized. The novel's open ending suggests that Jasmine's 'internarrative identity' is still in progress, for she still allows herself to be impacted by her diasporic condition in order to attain complete assimilation into American society.

As for Lahiri's Gogol, his 'internarrative identity' has been formulated through his negative attitude towards his name, pursuit of independence from his family culture, officially changing his name until eventually coming to terms with his ethnic background and namesake after his father's death. As has been mentioned earlier, lack of self-acceptance and social anxiety characterize Gogol's pre-college years. However, by joining university in another city, Gogol displaces himself from his family home to develop a sense of home in the family house of his girlfriend, Maxine. During this stage, he attempts to claim a new world, carve for himself a unique personal identity in a new place where everybody may know him as Nikhil instead of Gogol. Thus, he manifests a different identity crisis being the son of first-generation Indian immigrants, Ashoke and Ashima. He takes his first act of identity negotiation when he chooses to be called Nikhil instead of Gogol. According to Judith Caesar, 'Nikhil' is Gogol's 'overcoat' which covers his difference from other Americans $(2007,110)$. The new name enables him to belong to the American culture in which he was born, whereas 'Gogol' has alienated him from both his American culture and even the Indian one; it places him in a 'Third Space' that he loathed for so long. On his fourteenth birthday, Gogol received Nikolai Gogol's "The Overcoat" as a gift from his father, Ashoke, who declared that: "We all came out of Gogol's coat" (Lahiri 2004, 78), and knowing that his son is yet to appreciate his namesake, he only says to his agitated son that this statement "will make sense to [him] one day" (Lahiri 2004, 78). Ashoke can only hope that Gogol 
may, one day, understand that he is fortunate to have a multi-cultural background which his father has painstakingly pursued. Caesar believes that for Ashoke, "Gogol is a new life, a rebirth, the creation of another life in another country, both his own life and his children's" $(2007,110)$. By giving this name to his son, Ashoke has given Gogol more roots than he could understand or accept as a young boy. It was not until his father's death that Gogol experiences feelings of guilt for alienating his father and deprecating the valuable inheritance he meant to give him, i.e. a metaphorical 'overcoat' of a transnational identity that can entitle him to more than his father has been able to attain in his life.

Likewise, Mukherjee's Jasmine undergoes a process of identity-creation, a sort of metaphorical rebirth. In fact, the protagonist's experience of widowhood, immigration, rape, among others, have made her adamant on winning her battle against fate through self-transformation. Kristin Carter-Stanborn believes that Jasmine defines herself in terms of what she had to abandon (1994, 573). Before she comes of age, the young Jyoti fails to comprehend the self-creation motif in two English novels that she encounters: "I remember Great Expectations and Jane Eyre, both of which I was forced to abandon because they were too difficult" (Mukherjee 1989, 41). In other words, Jyoti, who was placed in the cultural context of rural India, was ill-equipped to understand these Western novels so she could not identify with their themes as they contradict her conventional upbringing. On a different note, the difficulty that Jyoti faces in reading the aforementioned texts may have propelled her to enhance her English proficiency, continue her school education, and grow to become the girl who cannot marry "a man who didn't speak English, or at least who didn't want to speak English [because for her] [t]o want English was to want more than you had been given at birth, it was to want the world" (68). Thus, Jasmine abandons the limitations of her traditional upbringing and is able to create an evolving 'internarrative' identity.

Contrary to the traditional depiction of arranged marriages which mostly undermine a girl's agency and independence, Mukherjee's Jasmine and Lahiri's Ashima have both gained agency thanks to their husbands. Indeed, Jyoti's marriage to the English-speaking enlightened Prakash has been a liberating, and life-altering experience, for he also wanted "more than [what he] had been given at birth" (Mukherjee 1989, 68). He taught her to reject the limitations imposed upon her by society and to live instead according to her own principles. In addition, his influence on her was so strong that his death turned her into a woman with a mission. She believes that: "It is [her] mission to bring [her] husband's suit to America. [She is] taking it to his school and burning it where 
[they] were going to live" (114). In other words, Jasmine performs what may be called a metaphorical Sati (the old Hindu ritual of a widow's self-burning after her husband's death as a token of faithfulness).

Rather than leading her life as a grieving widow or burning her own body, Jasmine travels to America to pursue her husband's dream and honor his soul. Upon arriving to America, she gets exposed to the danger of being a woman of color when she gets raped by Half-Face, the illegal ship captain, whose encounter has been a turning point in her life. Instead of feeling ashamed and victimized, she decides to kill Half-Face for all the psychological and physical damage he has caused her:

I could not see myself in the steamed-up mirror — only a dark shadow in the center of the glass. I could not see, as I had wanted to, an arm reaching to the neck, the swift slice, the end of my mission. It was the murkiness of the mirror and a sudden sense of mission that stopped me. What if my mission was not yet over? I didn't feel the passionate embrace of Lord Yama that could turn a kerosene flame into a lover's caress. (Mukherjee 1989, 117-18)

Her murky reflection in the mirror reflects her inability to identify herself which awakened her to the fact that she has a choice and a mission. She knows that she is meant for more than dying in a shabby hotel in repentance for an act of defilement she did not cause. Thus, she looks at herself and proceeds to cut her tongue with a knife to resemble Kali. In Hindu mythology, Kali is portrayed as a naked woman with four arms, wearing a necklace of cut heads. Suchismita Banerjee views Jasmine's metamorphosis into Kali as a manifestation of her individual agency which marks the first step in her journey towards asserting herself $(2012,19)$. After she murders Half-Face, Jasmine feels that her body "was merely the shell, soon to be discarded" (108), which is an attempt to absolve her body from the act of murder to move forward with her life without fear. In addition, from the point of view of Hinduism, this is an act of nonattachment in which she refrains from blaming herself for resorting to violence. Indeed, killing Half-Face was possible when Jasmine reincarnated herself as Kali. This act of murder is regarded by Banerjee as Jasmine's rite of passage into America (19) because by killing the rapist who manipulated her need for shelter, the protagonist kills the simple village girl she was before; she kills Jyoti and gives full reign to Jasmine who is prepared to embrace America and break away from the past. 
Indeed, Jasmine's journey of creating her destiny has been significantly affected by her husband, Prakash. Firstly, he is the one who gave her the name Jasmine and helped her to emancipate her mind: "Prakash had taken Jyoti and created Jasmine, and Jasmine would complete the mission of Prakash. Vijh \& Wife. A vision had formed" (Mukherjee 1989, 97). He represented the ambitious and adventurous spirit which is mandatory for the immigrant's successful survival in America. Inspired by Prakash, Jasmine says: "My husband was obsessed with passing exams, doing better, making something more of his life than fate intended" (85). Likewise, Jasmine becomes obsessed with getting ahead in life and defying the notion of a predetermined fate. Prakash helped Jasmine believe that "If [they] could just get away from India, ... all fates would be canceled. [They]'d start with new fates, new stars" (85). Accordingly, Jyoti allows Prakash to change her and liberate her from the conventional ideas that she inherited from her family.

Similarly, in Lahiri's The Namesake, marriage and motherhood are opportunities for identity construction. Through her arranged marriage to Ashoke, Ashima the educated Indian girl is introduced to a new reality. On Ashima's identity transformation, Ann Marie Alfonso-Forero writes that "the uncertain young woman we encounter in the novel's opening pages attempting unsuccessfully to recreate a favorite Indian snack in her Massachusetts kitchen is transformed through her role as an immigrant mother and wife into a transnational figure" $(2007,852)$. She transcends her ethnic identity and homesickness and evolves into a transnational figure, "[t]rue to the meaning of her name, she will be without borders, without a home of her own, a resident everywhere and nowhere" (Lahiri 2004, 276). Becoming a mother has obliged Ashima to gradually engage with American culture, for she needed to have a busy routine to overcome her loneliness as her husband was getting increasingly overwhelmed by his work and research. After she gave birth to Gogol, she realized that she had to learn independence to cope with her nostalgia and overcome her feelings of loneliness. The following excerpt illustrates her transition:

She cries as she feeds him, and as she pats him to sleep, and as he cries between sleeping and feeding. She cries after the mailman's visit because there are no letters from Calcutta .... One day she cries when she goes to the kitchen to make dinner and discovers that they've run out of rice. She goes upstairs and knocks on Alan and Judy's door. "Help yourself," Judy says, but the rice in Judy's 
canister is brown. To be polite, Ashima takes a cup but downstairs she throws it away. She calls Ashoke at his department to ask him to pick up the rice on his way home ... [and] when there is no answer, she gets up, washes her face and combs her hair. .... For the first time, she pushes [Gogol] through the balmy streets of Cambridge, to Purity Supreme, to buy a bag of white long-grain rice. The errand takes longer than usual; for now she is repeatedly stopped on the street, and in the aisles of the supermarket, by perfect strangers, all Americans, suddenly taking notice of her, smiling, congratulating her for what she's done. They look curiously appreciatively, into the pram. "How old?" they ask. "Boy or girl?" "What's his name?" (Lahiri 2004, 34)

The above extract highlights several aspects of Ashima's transition into independence and hybridity. The rice incident is significant not only because rice is an essential food staple that Ashima's household depended on, but mostly because it made her realize that she can overcome her sadness and isolation outside her domestic space. It gave her the chance to seek her neighbor's help and to go to the supermarket by herself which allowed her to engage with complete strangers who showed interest in her and her baby.

To take the argument a step further, it is crucial to analyze the protagonists' national and cultural identities against the backdrop of Indian nationalism. In The Nation and Its Fragments: Colonial and Postcolonial Histories, Partha Chatterjee explains that Indian nationalism divided culture into two spheres, namely, the material which includes the economic and modern aspects of life, and the spiritual which embodies traditions and beliefs $(1993,119)$. This division of culture dictated gender roles that Indians should perpetuate at home and abroad to preserve their national culture, and it allocated the material sphere to the man and the spiritual sphere to the woman. To overcome the Western hegemony over the material space, the Indians had to appropriate aspects of Western modernity and incorporate them within their own culture while protecting the sanctity of the spiritual realm where the East is considered "superior" (120). Hence, Indian women like Ashima were responsible for reviving their ethnic culture within the domestic space while men, like Ashoke, were expected to adapt to the demands of the material space and were encouraged to assimilate to the Western hosting culture.

Chatterjee elaborates on the above-mentioned domains by applying them to the dynamics of social life which she refers to as ghar (home) and bahir (the 
world) $(1993,120)$. Being responsible for the ghar domain where the family's spiritual essence is constructed, women seem to have a fundamentally bigger role than their male counterparts in shaping the identities of their children and the household. Alfonso-Forero rightly notes that Ashima's identity development represents the Indian middle-class 'new woman,' for she strove to preserve her family's ethnic identity or her ghar against the hegemonic US bahir in a manner that emulates older generations of new Indian women who decolonized their domestic spaces from the colonial British influence (854). Eventually, by placing herself in her domestic space as well as the public space, Ashima has developed a hybrid identity, for she continues to invoke her Indian past and revive it at home, in addition to inhabiting the American present and engaging with its culture.

Furthermore, Ashima has achieved cultural assimilation in her domestic space, Indian-American community, and American space. In her kitchen, as Anita Mannur points out, Ashima evokes a taste of home $(2010,14)$, where she prepares ethnic food as well as American food with Indian ingredients. At first, she and her husband used to predominantly prepare Indian food, but this changes after they become parents:

They learn to roast turkeys, albeit rubbed with garlic and cumin and cayenne, at Thanksgiving, to nail a wreath to their door in December, to wrap woolen scarves around snowmen, to color boiled eggs violet and pink at Easter and hide them around the house. For the sake of Gogol and Sonia they celebrate, with progressively increasing fanfare, the birth of Christ, an event the children look forward to far more than the worship of Durga and Saraswati. (Lahiri 2004, 64)

In fact, Ashima and Ashoke reach this level of integration thanks to the survival tactic which they gradually adopt, namely, replacing their extended families with the Indian immigrant community. Within this community, the Gangulis may assert their collective identity and create their 'imaginary homeland.' In their celebrations of ethnic feasts, Ashima and her fellow Indian wives endeavor to replicate India's taste in the meals they prepare for their families. As Eve Jackson asserts: "Sharing food is a fundamental bonding ritual in which we affirm our common identity as members of a family or group" (1996, 160). Accordingly, feasting and eating with fellow Indians help both Ashima and Ashoke overcome their feelings of rootlessness. Anita Mannur shares the same view of the unifying aspect of food sharing events, for she perceives of food making and sharing as a 
dominant aspect of the domestic sphere and an integral part of narratives about racial and ethnic identity as well as "an intractable measure of cultural authenticity" (Mannur 2010, 3). Hence, Ashima's domestic space manifests her hybridized identity in terms of protecting her Indian heritage and appropriating the American culture.

After her children move out, Ashima engages more with the American public sphere. She takes a part-time job at the local public library where she befriends Americans for the first time in her life. Later, her husband leaves for a better job in Cleveland, and she stays on her own in the Pemberton Road house. She reads books in the crafts section and makes Christmas greeting cards to send to her family members as well as to her Bengali and American friends. Because of her attachment to her roles as a wife and a mother, she does not experience solitary life until she is forty-eight. This is when "she has come to experience the solitude that her husband and son and daughter already know, and which they claim not to mind" (Lahiri 2004, 161). The more she places herself within the domestic and public American space, the more adaptable to independent life she becomes.

It could be said that the more Ashoke engages with the American public sphere, the more his wife is prepared to do the same. He teaches her how she can live in America on her own by seeking opportunity wherever it presents itself and avoiding indulgence in nostalgia. When he accepts a job offer in Cleveland, he gives Ashima the choice to move with him or not; having experienced the predicaments of displacement and loneliness before, she chooses not to move with him. His absence gives her the chance to blend more with the American community, so on some occasions "she has her library friends over to the house for lunch, goes shopping with them on weekends to outlet stores in Maine" (Lahiri 2004, 163). Being less burdened by family duties, Ashima grows to think of herself more as an independent person. She begins to comprehend that her home and identity are not bound by her relationship to other people. Reflecting on her husband's death, she says "Now I know why he went to Cleveland. ... He was teaching me how to live alone" (183). A lesson that helps her survive his death and embrace her hybrid identity, for now she understands that she is no longer the same Ashima she was when she left India for the first time. Nevertheless, she still holds her Indian heritage as a sacred possession.

In contrast to Ashima, Mukherjee's Jasmine uses her domestic American space not to achieve hybridity, but rather to completely assimilate to America. With Bud Ripplemeyer, the American banker who falls in love with her, Jasmine transforms into Jane Ripplemeyer, the Americanized exotic woman. In his household, she selectively projects her Indianness to maintain his interest and 
his family's acceptance: "People are getting used to some of my concoctions, even if they make a show of fanning their mouths. They get disappointed if there's not something Indian on the table" (Mukherjee 1989, 9). Her means of cultural integration is to please her guests through her ethnic cuisine. Thus, she seeks to manipulate the domestic sphere to be integrated within the American community through emphasizing her exotic flare.

This dominant position is illustrated through Sarah Sceats' article "Eating the evidence: Women, power and food" where she points out that the cultural connection between women and food places the woman in a position of power as she becomes a source of nourishment, controlling those "within the sphere of her catering" $(2014,123)$. Sceats contends that "a whole gamut of hierarchical relations is called into question, through eating interactions, appetites and primal desires" (117). In fact, Jane's "concoctions" are a deliberate use of power, for she manipulates the food ingredients to create a sort of addictive taste that Bud and his family are getting accustomed to. Not only does she succeed in pleasing them, she also relatively controls their appetites, for they feel frustrated when Indian food is not served at the table. Hence, Jasmine/Jane empowers herself through manipulating her migrant condition. She actualizes Salman Rushdie's description of the migrant's role in the target culture, as he states that "to migrate is to experience deep changes [...] but the migrant is not simply transformed by his act, he also transforms the new world [...] it is out of such hybridization that newness can emerge" $(1992,210)$. This is what Jane does when she proudly says "I'm subverting the taste buds of Elsa County. I put some of last night's matar panir in the microwave. It goes well with pork, believe me" (Mukherjee 1989, 19). She is subverting the Americans' taste and is also subverting her ethnic food, for she hybridizes an originally vegetarian Punjabi dish 'matar panir' by serving it with pork which is suggestive of her fluid identity.

Nevertheless, in the public sphere, Jasmine attempts to hide her Indianness through mimicking the dominant culture. In fact, she learns the laws of survival in America through Lillian Gordon, the American woman who gave her shelter after the rape incident. Before teaching Jasmine how to independently survive in America, Lillian gives her an American nickname, Jazzy, and advises her to have "low tolerance for reminiscence, bitterness or nostalgia. Let the past make you wary, by all means. But do not let it deform you" (Mukherjee 1989, 131). Furthermore, Lillian teaches Jazzy how to talk and walk like Americans to easily integrate with them: "if you walk and talk American, they'll think you were born here. Most Americans can't imagine anything else" (134-35). These are the visible elements of cultural assimilation that Jasmine needs to master to protect 
herself from looking like a miserable undocumented alien to spare herself racial discrimination, let alone deportation, if she is caught. When Lillian teaches her to ride her first escalator, she warns her: "They pick up dark people like you who're afraid to get on or off" (133). Unless Jasmine demonstrates a fluid mutable identity, she will be unable to integrate in America. In other words, she needs to be Jazzy, the Americanized woman who exudes confidence, and to suppress the insecure woman inside her.

To be genuinely liberated from the past, Jazzy endeavors to normalize her foreignness. As Inderpal Grewal argues, America gives Jasmine something that India did not, which is the choice of becoming who she dreams to be, which is more than what she was destined to become in India $(2005,69)$. To become American, Mukherjee's protagonist realizes that she needs to unlearn some of the Indian values that will not serve her in her new abode. In addition, she also needs to adopt American cultural norms and values as closely as possible to secure herself: "I worked hard on the walk and deportment. Within a week she said I'd lost my shy sidle" (Mukherjee 1989, 132-33). This shows how Jazzy gets liberated and empowered by mimicking the Other and breaking away from her past. Having abandoned her shyness, she "couldn't tell if with the Hasnapuri sidle [she]'d also abandoned [her] Hasnapuri modesty" (133). At this stage, Jazzy feels suspended between the past and the present, between the homeland she left behind and the host land to which she chooses to belong.

An essential aspect of Jane's identity is that she deviates from the female stereotype in several ways. In spite of demonstrating a pattern of dependency in her relationships with most men she comes in contact with, Jane adopts a powerful position in her relationship with Bud. According to Bell Hooks, when a man is dominant, he describes himself as the subject, which relegates the woman to an object. Being the object entails that one "is defined by others, one's identity created by others, one's history named only in ways that defines one's relationship to those who are subject" $(1989,42-43)$. However, through her refusal to marry Bud, she ensures her independence and her dominance because according to her cultural heritage, the woman becomes a follower of her husband, a role which she cannot play after Prakash's death: "for Indian women to assert their identity, they must resist or transgress the marriage institution. Defying the patriarchal system and claiming one's individuality can only take place in America" (Shah 2014, 87). Thus, Jane continues to live with Bud out of wedlock to deny him control over her future, defying her cultural norms which oppose such cohabitation. 
To conclude, it is obvious that Jasmine's identity transformation has led her to mentally navigate the distance between two worlds, so she has reached a stage of in-betweenness. From this position, the heroine negotiates her identity to disengage herself from her home culture with its strict gender roles to assimilate to the American culture with its promises of freedom to create one's destiny. The feeling of entrapment which she experienced in her homeland is the catalyst that prompts her to keep running away and recreating herself. It reminds her of the lessons of freedom that her deceased husband had taught her. However, Lahiri's Gogol and Ashima experience a special kind of identity negotiation. Being a second-generation Indian immigrant continues to be an important factor in the American-born Gogol and it continues to shape his identity. It is only when he identifies with both sides of his identity that he can attain a more stable sense of self. As for Ashima, she learns to place herself in the American culture as her new adoptive home while maintaining her ties to her homeland. She gradually accepts her transnational identity, acknowledging, thus, her belonging to both countries and the impact they both have on her. Along the narrative of alienation, the protagonists' identities unfold and transform in manners they have not anticipated. The dislocation from home becomes an empowering experience for the protagonists who attempt to actively assimilate to their adopted country without being hindered by their ethnic difference. Certainly, this empowerment is not a simple outcome of crossing borders; it is rather a product of the protagonists' idiosyncratic experiences and dilemmas which lead to their identity transformations.

\section{Works Cited}

Alfonso-Forero, Ann Marie. 2007. "Immigrant Motherhood and Transnationality in Jhumpa Lahiri's Fiction." Literature Compass 4, no.3 (May): 851-61. <https://doi:10.1111/j.1741-4113.2007.00431.x>.

Ashcroft, Bill, Gareth Griffiths and Helen Tiffin, eds. 1998. Key Concepts in Post-Colonial Studies. London: Routledge.

Banerjee, Suchismita. 2012. "Interrogating the Ambivalence of Self-Fashioning and Redefining the Immigrant Identity in Bharati Mukherjee's Jasmine." Asiatic 6, no. 1, (June): 10-24.

http://journals.iium.edu.my/asiatic/index.php/AJELL/article/view/232

Bhatia, Sunil. 2007. American Karma: Race, Culture, and Identity in the Indian Diaspora. New York: New York UP. 
Caesar, Judith. 2007. "Gogol's Namesake: Identity and Relationships in Jhumpa Lahiri's The Namesake.” Atenea 27, no.1 (June): 103-119. http://indianliterature.co.za/wp-content/uploads/2012/07/Caesar-GogolsNamesake.pdf

Carter-Sanborn, Kristin. 1994. "We Murder Who We Were': Jasmine and the Violence of Identity." American Literature 66, no. 3 (September): 573-93. $<$ https://doi: 10.2307/2927605>.

Chatterjee, Partha. 1993. The Nation and Its Fragments: Colonial and Postcolonial Histories. Princeton, NJ: Princeton UP.

Gilroy, Paul. 1993. The Black Atlantic: Modernity and Double Consciousness. New York: Verso.

Goffman, Erving. 1956. The Presentation of Self in Everyday Life. Edinburgh: U of Edinburgh's Social Sciences Research Centre.

Grewal, Inderpal. 2005. Transnational America: Feminisms, Diasporas, Neoliberalisms. Durham and London: Duke UP.

Hall, Stuart. 1990. "Cultural Identity and Diaspora." In Identity: Community, Culture, Difference, edited by Rutherford Jonathan, 222-37. London: Lawrence \& Wishart.

Hooks, Bell. 1989. Talking Back: Thinking Feminist, Thinking Black. Boston, MA: South End P.

Jackson, Eve. 1996. Food and Transformation Imagery and Symbolism of Eating. Toronto: Inner City Books.

Lahiri, Jhumpa. 2004. The Namesake: A Novel. Boston: Houghton Mifflin Harcourt.

Maan, Ajit K. 2010. Internarrative Identity: Placing the Self. Lanham, MD: UP of America.

Mannur, Anita. 2010. Culinary Fictions: Food in South Asian Diasporic Culture. Philadelphia, PA: Temple UP.

Miller, Cynthia J. 2008. "Immigrants, Images and Identity: Visualising Homelands Across Borders." In Tracing an Indian Diaspora: Contexts, Memories, Representations, edited by Parvati Raghuram, Ajaya Kumar Sahoo, Brij Maharaj, and Dave Sangha, 284-98. New York: Sage.

Mishra, Vijay. 2007. The Literature of the Indian Diaspora: Theorizing the Diasporic Imaginary. London: Routledge.

Mukherjee, Bharati. 1989. Jasmine. New York: Grove/Atlantic, Inc., 2007.

Oonk, Gijsbert. 2007. Global Indian Diasporas: Exploring Trajectories of Migration and Theory. Amsterdam: Amsterdam UP. 
Ranasinha, Ruvani. 2016. Contemporary Diasporic South Asian Women: Gender, Narration and Globalization. New York: Macmillan.

Ricoeur, Paul. 1991. "Narrative Identity." Philosophy Today 35, no. 1 (Spring): 73-80. <https://doi: 10.5840/philtoday199135136>.

Rushdie, Salman. 1992. Imaginary Homelands: Essays and Criticism 19811991. London: Granta Books.

Said, Edward. 2013. Reflections on Exile: And Other Literary and Cultural Essays. London: Granta Publications.

Sceats, Sarah. 2014. "Eating the evidence: Women, power, and food." In Image and Power: Women in Fiction in the Twentieth Century, edited by Sarah Sceats and Gail Cunningham, 117-27. London: Routledge.

Shah, Nandini. 2014. "Reconsidering Bharati Mukherjee: The Dissolution of Dialectics in Desirable Daughters." Research Journal of English Language and Literature 2, no.1. (March): 85-95. http://www.rjelal.com/vol.2.issue \%201\%202014.html

Singh, Amritjit and Peter Schmidt. 2000. Postcolonial Theory and the United States. Jackson, MS: U of Mississippi P.

Slemon, Stephen. 1995. "The Scramble for Post-colonialism." In The Postcolonial Studies Reader, edited by Bill Ashcroft, Gareth Griffiths, and Helen Tiffin, 45-52. London: Routledge. 